\title{
Frontiers of popular physics demonstrations
}

\author{
Guillaume Trap* \\ Palais de la découverte \\ E-mail: guillaume.trapeuniverscience.fr
}

\begin{abstract}
Notwithstanding the proliferation of virtual tools of scientific communication, the use of real experiments presented live by science explainers remains extremely precious. Beyond obvious pedagogical and epistemological benefits, a demonstration is also source of ethical and esthetical reflections [1]. We will discuss some aspects and practical modes of the implementation of experimental popular fundamental physics shows (as performed in science museums in particular) according to the nature of the targeted public and the phenomena popularized.

References

[1] Trap, G. (2011). Le spectacle de la nature. In A. Giordan, J.-L. Martinand \& R.-E. Eastes (Eds.), L'idée de nature dans la médiation et l'éducation scientifiques, Actes des 3les Journées internationales de l'éducation scientifique, (12 pages).
\end{abstract}

Frontiers of Fundamental Physics 14 - FFP14,

15-18 July 2014

Aix Marseille University (AMU) Saint-Charles Campus, Marseille

${ }^{*}$ Speaker. 